\title{
PROMOTING \\ A LOOK BEYOND \\ STEREOTYPED CULTURAL \\ REPRESENTATIONS IN \\ TELETANDEM
}

\section{PROMOVENDO UM OLHAR PARA ALÉM DE REPRESENTAÇÕES CULTURAIS ESTEREOTIPADAS NO TELETANDEM}

\author{
PROMOVIENDO UNA MIRADA MÁS ALLÁ DE REPRESENTACIONES CULTURALES \\ ESTEREOTIPADAS EN TELETANDEM
}

Rodrigo Schaefer*

Instituto Federal Catarinense | campus Brusque

\begin{abstract}
Cultural representations, which arise out of interaction between individuals from different cultures, "convey images or narratives of culture and society" (RISAGER, 2007, p. 180). Teletandem, according to Telles (2015a, p. 604), is "a mode of telecollaboration - a virtual, collaborative and autonomous context for learning foreign languages" in which two students swap their roles: at times as learners of a foreign language and at other times as tutors of their mother tongue or other languages. This study aimed at discussing how the overcoming of stereotyped cultural representations occurred in the teletandem context investigated. For the analysis, data from a teletandem session, a mediation session, experience reports and interviews were included. The results showed that the overcoming of stereotyped cultural representations, made possible by a decentering attitude (KRAMSCH, 2011; LIDDICOAT; SCARINO, 2013), was a process, that is, it occurred over time and through different instances.

KEYWORDS: Teletandem. Telecollaboration. Cultural representations. Interculturality. Online teaching and learning of foreign languages.
\end{abstract}

RESUMO: As representações culturais, que surgem da interação entre indivíduos de diferentes culturas, "expressam imagens ou narrativas de cultura e sociedade" (RISAGER, 2007, p. 180, minha tradução). O teletandem, de acordo com Telles (2015a, p. 604), refere-se a "uma modalidade de telecolaboração - um contexto virtual, colaborativo e autônomo para o aprendizado de línguas estrangeiras" (minha tradução) em que dois estudantes trocam de papéis: ora como aprendizes de uma língua estrangeira, ora como tutores da língua materna ou de outras línguas. O presente estudo teve o objetivo de discutir como ocorreu a superação de representações culturais estereotipadas no contexto do teletandem investigado. Para as análises, foram incluídos dados de uma sessão de teletandem, uma sessão de mediação, relatos de experiência e entrevistas. Os resultados mostraram que a superação de

* English and Portuguese teacher at Instituto Federal Catarinense (IFC) campus Brusque. Doctorate in Inglês: Estudos Linguísticose Literáriosfrom Universidade Federalde SantaCatarina (UFSC). E-mail: rodrigo.schaefer@ifc.edu.br. 
representações culturais estereotipadas, viabilizada por uma atitude de distanciamento (KRAMSCH, 2011; LIDDICOAT; SCARINO, 2013), foi um processo, isto é, ela ocorreu ao longo do tempo e através de diferentes instâncias.

PALAVRAS-CHAVE: Teletandem. Telecolaboração. Representações culturais. Interculturalidade. Ensino e aprendizagem de línguas estrangeiras online.

RESUMEN: Las representaciones culturales, que surgen de la interacción entre individuos de diferentes culturas, "expresan imágenes o narrativas de cultura y sociedad" (RISAGER, 2007, p. 180, traducción propia). Teletandem, de acuerdo con Telles (2015a, p. 604), se refiere a "una modalidad de telecolaboración - un contexto virtual, colaborativo y autónomo para el aprendizaje de lenguas extranjeras" (traducción propia) en la que dos estudiantes intercambian roles: a veces como aprendices de una lengua extranjera, a veces como tutores de la lengua materna u otras lenguas. El presente estudio tuvo como objetivo discutir cómo ocurrió la superación de representaciones culturales estereotipadas en el contexto del teletandem investigado. Para los análisis, se incluyeron datos de una sesión de teletandem, una sesión de mediación, informes de experiencias y entrevistas. Los resultados mostraron que la superación de representaciones culturales estereotipadas, viabilizada por una actitud de distanciamiento (KRAMSCH, 2011; LIDDICOAT; SCARINO, 2013), fue un proceso, es decir, ocurrió con el tiempo y a través de diferentes instancias.

PALABRAS CLAVE: Teletandem. Telecolaboración. Representaciones culturales. Interculturalidad. Enseñanza y aprendizaje de lenguas extranjeras en línea.

\section{INTRODUCTION}

Made it possible by the advent of the Internet, a profusion of digital resources such as maps, videos and images has helped users to learn other languages. For O'Dowd (2007), the use of digital communication tools in the area of foreign language teaching and learning allows for the contact between members of different cultures. In fact, telecollaborative exchanges can foster this contact. For O'Dowd (2013, p. 123), telecollaboration can be understood as "the application of online communication tools to bring together classes of language learners in geographically distant locations to develop their foreign language skills and intercultural competence through collaborative tasks and project work".

One example of telecollaboration is teletandem (TELLES; VASSALLO, 2006; VASSALLO; TELLES, 2006; VASSALLO, 2009; TELLES, 2011, TELLES, 2015a, 2015b), which is also the specific context of this study. Telles (2015a, p. 604) summarizes teletandem as follows: "A mode of telecollaboration - a virtual, collaborative and autonomous context for learning foreign languages in which two students help each other to learn their own languages (or language of proficiency). They do so by using the text, voice and webcam image resources of VOIP ${ }^{1}$ technology (such as Skype $\left.{ }^{2}\right)^{\prime}$.

Teletandem has three guiding principles: reciprocity, autonomy, and separate use of languages (TELLES, 2015b). Reciprocity concerns a mutual support and interdependence between the two language learners (BRAMMERTS, 1996), whereas autonomy refers to the commitment of both interactants ${ }^{3}$ regarding their own learning process. Lastly, separate use of languages means that the two languages cannot be mixed (TELLES, 2015b).

Cultural representations emerge when individuals from different countries and cultures come into contact. For Risager (2007, p. 180), these representations "convey images or narratives of culture and society in particular contexts". Having in mind that, as was

\footnotetext{
${ }^{1}$ VOIP - Voice over Internet Protocol.

${ }^{2}$ Skype is a software that provides voice and video communications via the Internet.

3 "Interactants" is the name given to the two partners who are learning each other's language in teletandem sessions. Sometimes I will make use of "interactant(s)" instead of "participants", even though most of times I use the latter.
} 
explained earlier, telecollaboration provides the contact among people from different cultures, this study ${ }^{4}$ aimed at discussing how the overcoming of stereotyped cultural representations occurred in the teletandem context investigated. To achieve this objective, I outlined the following research question: how did the overcoming of stereotyped cultural representations occur in the teletandem context investigated?

The way in which this study can contribute to the teletandem context can be explained in the sense that the need to look at cultural aspects in the teletandem context was pointed out by Telles (2011). Similarly, Telles (2015b, p. 4) highlights that "the intercultural dimension of teletandem interactions has not been sufficiently explored". In this way, this study seeks to bridge a gap by focusing on cultural representations in this telecollaborative context.

\section{REVIEW OF LITERATURE}

\subsection{TELECOLLABORATION AND TELETANDEM}

It can be said that the intercultural dialogue is at the heart of researchers on telecollaboration. For instance, Helm (2016, p. 153) underscores that dialogue "entails critical thinking and aims to reveal assumptions and biases, so they can be re-evaluated". It is through dialogue, therefore, and by working collaboratively that "participants explore identities and difference, personal experience and emotions, which contribute to awareness of self and others" (HELM, 2016, p. 153). O'Dowd (2003, p. 133), in turn, asserts that the intercultural dialogues "allow learners to express their ideas and then to clarify and redefine them through feedback and through the other perspectives to which they are exposed". Finally, Veloso and Almeida (2009) argues that dialogue in teletandem enables interactants to take a major control over the learning process, which prevents them from being consumers of teaching syllabus.

Cultural differences, according to Belz (2005), Ware (2005), Helm (2016) and O’Dowd (2016), are not often discussed in more depth in telecollaborative exchanges, and the discussion about such cultural differences is frequently averted. For Helm (2016, p. 151), this happens because language learners' focus "is on phatic exchanges between learners and [there is] a concern to avoid tensions and misunderstandings". As stated by O'Dowd (2016, p. 277), learners do not go deeper in cultural differences because they tend to pay more attention to "what cultures may have in common at a superficial level", which can "have little effect on students' understanding of the partner culture or to lead to a critical reflection on students' own culture" (p. 277). In addition, avoiding deeper discussion "can lead to "missed" communication, or missed opportunities for approximating the kind of rich, meaningful intercultural learning that instructors often intend with telecollaborative projects" (WARE, 2005, p. 66). As a result of the superficial level of exploration, Belz (2005, p. 27) alerts that online exchanges may result in the "retreating into self, reinforcing stereotypes and myths and even creating new, more negative stereotypes".

According to Telles (2015a), teletandem was conceived and developed based on Sociocultural Theory, in the sense that knowledge is socially co-constructed through language (VYGOTSKY, 1978). Vygotsky (1978) argues that learning happens first socially and, subsequently, higher mental functions are developed. Furthermore, the author explains that historical and cultural features contribute to this development. From this perspective, individuals are part of a particular cultural context through which they learn by co-constructing and negotiating social meanings.

Vygotsky (1981) posits that the transformations of individuals occur on the basis of four genetic domains: phylogenetic ${ }^{5}$, sociocultural ${ }^{6}$, microgenetic and ontogenetic, and the two latter, as will be seen in the discussion of the data analysis further along, are

\footnotetext{
${ }^{4}$ This article is from my PhD dissertation, which was completed in 2019 at UFSC.

5 "Phylogenetic" refers to the evolution of living organisms by means of their gradual adaptation to the environment. This evolution occurs through a slow process of transformation over long periods of time.

6 "Sociocultural" since social interactions are the basis of higher cognitive processes.
} 
fundamental in this work. Microgenetic is related to specific situations that are experienced by individuals, which can modify their mental functions. Ontogenetic, on the other hand, involves the whole history of each individual, and the different transformations that, through dialectical interactions, occur along her/his life, from birth to adulthood. From this perspective, Van Lier (2004, p. 12) claims that the ontogenetic realm "includes the interactional processes in which social meanings become internalized, and the use of language and signs, linked with the development of higher mental functions".

The thematic project teletandem Brasil: foreign languages for all (henceforward TTB) was created in 2006 (TELLES; VASSALLO, 2006; VASSALLO; TELLES, 2006). It is run at a state university in São Paulo's countryside by researchers, practitioners, and teachers with the purpose of enabling college students from Brazil to interact with college students from other countries.

Since 2011, this project has been called Teletandem: Transculturality in online communication in foreign language by webcam and the cultural component has been given special attention. Telles (2011) highlights that the TTB project, until the year of publication of its new version (2011,p. 4), had not "deepened the growing evidence that emerged over the studies of teletandem as a learning context of cultural aspects inherent in the virtual communication in teletandem" (my translation ${ }^{7}$ ).

In most telecollaborative projects reported in research "teachers organize the communication and tasks, motivate students, monitor activities and provide feedback and support for learners, but the communication between learners is not usually moderated" (HELM, 2016, p. 151). Specifically concerning the teletandem context, the online sessions themselves are not moderated by a teacher-mediator either. Mediation sessions (ROCHA; LIMA, 2009; TELLES, 2015b, LEONE; TELLES, 2016; LOPES; FRESCHI, 2016) are nevertheless an essential way of facilitating, according to Lopes and Freschi (2016), moments of further reflection and the questioning of essentialist views. Leone and Telles (2016, p. 244) define mediation session as follows:

Moments that follow interactions in teletandem. During these sessions, students have the opportunity to dialogue and exchange experiences with a mediator - a teacher of foreign languages. These discussions focus on (a) aspects of language, (b) culture and (c) partners' relationship. The mediation activity aims at giving students a teacher supported context $\left(\right.$ scaffolding $\left.^{8}\right)$ to reflect on the teaching and the learning experiences during the teletandem session.

Rocha and Lima (2009) make clear that the teacher-mediator's role in the teletandem context is to mediate the contact between Brazilians and foreigners. The authors highlight that it is necessary to stress to learners the importance of respecting their online partner's individuality. By the same token, they should pay attention to cultural differences, for the sake of not negatively affecting the language learning process, causing possible constraints or the eventual partnership breakdown.

\subsection{CULTURAL REPRESENTATIONS AND INTERCULTURALITY}

As there is the tendency to perceive other people as representatives of a certain nationality (BYRAM, 1997), cultural representations come into play when individuals meet in telecollaborative exchanges. Jovchelovitch (2007, p. 11) makes clear that "[...] the reality of the human world is in its entirety made of representation: in fact, there is no sense of reality for our human world without the work of representation".

According to Hall (1997, p. 15), "[...] representation is an essential part of the process by which meaning is produced and exchanged between members of a culture". He asserts that cultural representations allow individuals to construct their identities and to intersubjectively exchange meanings about the "real" and "imaginary" worlds linked to people, objects, and event. From this perspective, Dervin (2014, p. 194) states that people use cultural representations to position themselves and "to claim common

\footnotetext{
${ }^{7}$ Original quote: "aprofundou nas crescentes evidencias surgidas ao longo dos estudos acerca do teletandem como um contexto de aprendizagem de aspectos culturais inerentes à comunicação virtual em teletandem”.

${ }^{8}$ For Wood, Bruner and Ross (1976, p. 90), "scaffolding" is a support mechanism that "enables a child or novice to solve a task or achieve a goal that would be beyond his unassisted efforts".
} 
identities" and adds that the more people interact with others in a variety of contexts, "the more varied representations one coconstructs and re-interprets" (p. 194). Despite this, Byram, Gribkova and Starkey (2002, p. 9, p. 27) warn that some cultural representations can cause the emergence of stereotypes, which "are based on feelings rather than reason".

In line with an intercultural approach (KRAMSCH, 1993, 2005, 2011, 2013; BYRAM, 1997; BYRAM; GRIBKOVA; STARKEY, 2002; GIL, 2016), having the ability to interact effectively with people from different cultures involves being able to overcome stereotyped representations, since they can trigger negative visions of other groups (BYRAM, 1997). In order for this to happen, Byram, Gribkova and Starkey (2002, p. 25) claim that foreign language teaching should help students "to examine and challenge generalizations or stereotypes, and suggest or present other viewpoints". Furthermore, Liddicoat and Scarino (2013, p. 42) assert that a decentering process from fixed cultural representations may lead to the "transformational engagement of the learner".

Looking beyond stereotyped cultural representations, gaining knowledge of other people's values and behaviors, respect for other cultures, adaptation to different contexts, openness to other viewpoints and personal desire to know other cultures are relevant aspects when it comes to the construction of interculturality, which Byram (1997) actually names intercultural communicative competence. For him, this term is related to the ability to use language in interactions with people from other cultures. He adds that for the development of such a competence it is paramount that language learners "elicit from an interlocutor the concepts and values of documents and events" (p. 53).

Byram (1997) proposes five components for the development of intercultural communicative competence, namely: (1) attitudes, which are related to a "willingness to suspend belief in one's own meanings and behaviors, and to analyze them from the viewpoint of the others with whom one is engaging" (p. 34); (2) knowledge, referring to knowledge of other cultures and the self in social interactions; (3) skills of interpreting and relating, that is, "the ability to acquire new knowledge of a culture and cultural practices and the ability to operate knowledge, attitudes and skills under the constraints of real-time communication and interaction" (p. 61); (4) skills of discovering and interacting, meaning that it is necessary to have the ability to interpret documents or events of other cultures and relate them to her/his own cultural horizons; and (5) critical cultural awareness, which stands for the examination and interpretation of cultural differences.

Kramsch (1993) explains that meaning-makings are an interpersonal process since they emerge through interaction with "the other". This way, the reflection between "the self" and "the other" in intercultural interaction presupposes the deconstruction of stereotyped cultural representations as well as of the world itself. Kramsch $(2005$, p. 553) adds that such a reflection can lead to interculturality, which is related to "an awareness and a respect of [sic] difference, as well as the socio-affective capacity to see oneself through the eyes of others".

In 1993, Kramsch coined the term the third place, which concerns hybrid space where a constant mediation between different cultures occurs. At the third place, such a mediation can help language learners to decenter themselves from cultural representations. More recently, Kramsch (2011, p. 354-355) defined third place as "a sphere of interculturality that enables language students to take an insider's view as well as an outsider's view" regarding cultural representations.

The third place can be associated with two metaphors: discursive faultlines (KRAMSCH, 1993; MENARD-WARWICK, 2009) and transgredience (KRAMSCH, 2013). For Kramsch (1993), discursive faultlines involve the moments in which cultural representations are contested at the third place. As explained by Menard-Warwick (2009, p. 30), these discursive faultlines, that is, "areas of cultural difference", are "pedagogically valuable because they index the cultural areas that need to be explored in order to work toward interculturality" (p. 30). The second metaphor, transgredience (KRAMSCH, 2013, p. 62), is related to the idea that language learners, through a critical eye, can "occupy a position where they see themselves both from the inside and from the outside" as well as "reflect on their experience". According to Byram, Gribkova and Starkey (2002, p. 29), such a critical stance can help language learners "to act on a [sic] the basis of new perspectives". In what follows, I will present four studies whose focus was placed on intercultural meetings in the teletandem context. 
Mendes's (2009) study had the purpose of understanding the beliefs of undergraduate English teachers regarding English language and the United States, as well as the implications of a growing worldwide sense of anti-Americanism in this context. Some of these feelings of anti-Americanism exposed by some participants were "America as a superpower in decline" and "America as the center of the world". Despite this sense of anti-Americanism, the data analysis revealed the coexistence of feeling of admiration and "of adoration regarding everything linked to the EUA (...) characterizing a conflict of beliefs about that country" (p. 97, my translation $\left.^{9}\right)$.

The objective of Salomão's (2011) study was to analyze Brazilian in-service teachers' concepts and beliefs regarding language and culture. She underlines that before the teletandem sessions started, the teachers had a static and factual view of culture, but after these sessions they came to see it also as an interpersonal process. The author suggests that, in order to favor the conception of culture as an interpersonal process which is characterized by elements such as "pluralization of one's cultural identity" (HALL, 2006 apud SALOMÃO, 2011, p. 272), the view of culture in the teletandem context should go beyond the transmission and explanation of national cultural references.

Telles's (2015b) study aimed at showing how Performative Theory ${ }^{10}$ can help to understand the way in which the constitution of national identities occurs. The author (p. 5) argues that "teletandem discourse is basically characterized by performances of differences". Furthermore, he alerts that teletandem sessions "may fall into shallow performances of sedimented and pre-given representations of self and other", meaning that the discussions in teletandem "involve common sense, and are essentialist in nature" (p. 4). The analysis showed that teletandem is a context where participants can express ideologies and their subjectivities. Although Telles did not analyze data from mediation sessions, he points out that these moments can promote critical thinking as well as "critical appreciation of identity and difference" (p. 25) if appropriately and critically explored by teacher-mediators.

Lopes and Freschi's (2016) study sought to discuss the relevance of the identification of potential sequences for intercultural learning (BORGHETTI; BEAVEN; PUGLIESE, 2015) ${ }^{11}$. Through the analysis, the authors identified potential sequences, e.g. prejudice and essentialized worldviews, for intercultural learning. They argue that "what an interactant says about herself/himself, about her/his culture and her/his people is not usually questioned by her/his partner" (p. 55, my translation ${ }^{12}$ ) in the teletandem sessions. The authors did not include data from mediation sessions in their corpus, but they indicated the relevance of addressing in these sessions topics that were previously identified in teletandem sessions as potential sequences for intercultural learning.

As can be seen, in both Telles's (2015b) and Lopes and Freschi's (2016) study it was pointed out that research dealing with fixed cultural representations in mediation sessions is necessary. This is because teletandem sessions can be a site for the construction of essentialized visions as regards people, countries, cultural references, and so forth.

In short, given that telecollaborative spaces facilitate the dialogue between people from different cultures, they can open pathways for the reflection between "the self" and "the other", which, as a result, may help in the overcoming of stereotyped cultural representations. Additionally, especially under the guidance of a teacher-mediator, dialogue, according to Byram, Gribkova and Starkey (2002, p. 29), can help language learners to "to step outside their taken for granted perspectives", whilst for Liddicoat and Scarino (2013, p. 116) it makes it possible "to see the unfamiliarity of the cultural representations".

\footnotetext{
${ }^{9}$ Original quote: "de adoração por tudo que esteja ligado aos EUA (...) caracterizando um conflito de crenças a respeito daquele país".

${ }^{10}$ For Kulick (2003 apud TELLES, 2015b, p. 6), "performativity is the process through which the subject emerges" (p. 140).

${ }^{11}$ For Borghetti et al (2015), such potential sequences involve the following: "(1) exemplifications and equivalences between phenomena; (2) communicating understanding to others and; (3); adapting to others' contributions (p. 44).

${ }^{12}$ Original quote: “aquilo que um interagente diz de si mesmo, de sua cultura e de seu povo não costuma ser questionado pelo parceiro”.
} 


\section{METHOD}

The data used in this study ${ }^{13}$ were collected in TTB between September and December 2016. During that period, the author was a teacher-mediator and collected data for his doctoral research ${ }^{14}$.

As will be explained below, this qualitative research can be deemed as a case study (FALTIS, 1997) because it focused on a contemporary phenomenon in its real context. Faltis (1997, p. 146) suggests that "interpretive case studies in language and education are analytical descriptions that illustrate, support or challenge existing theoretical assumptions about teaching and learning”.

Thus, precisely because it is a case study, this investigation included two participants in particular regarding the teletandem sessions: Heitor and Betha ${ }^{15}{ }^{16}$. They were part of a teletandem partnership between a state university in Brazil, where TTB is developed, and a university in the United States. Heitor, a Brazilian 21-year-old English learner at the time of the data collection, interacted with Betha, an American 19-year-old Portuguese learner.

The data used in this study are from a teletandem session, a mediation session, experience reports and semi-structured interviews. The teletandem session between Heitor and Betha took place through the application $Z_{0 o m}{ }^{17}$ and was video-recorded. In the mediation sessions, which occurred soon after the teletandem sessions, Heitor, other participants ${ }^{18}$ of the Brazilian university and the teacher-mediator were able to discuss several aspects related to the online sessions. Through experience reports via Google Forms ${ }^{19}$, Heitor had the opportunity to collect his thoughts and submit personal impressions regarding his weekly partnership with Betha. Heitor also participated in interviews, through which I could better understand what he had addressed in his experience reports. The interviews and the mediation session were audio-recorded.

For Dörnyei (2007, p. 38), in qualitative research the findings are "[...] ultimately the product of the researcher's subjective interpretation of the data". In fact, the data collected underwent a long process of interpretation and reflection. Therefore, to understand the way in which the overcoming of stereotyped cultural representations occurred, I triangulated my interpretations concerning the data from the teletandem session with the data from the mediation session as well as with Heitor's experience reports and the interviews. As stated by Maxwell (1996), triangulation decreases the risk that the outcomes of a study reproduce biases or limitations of a single procedure.

The excerpts analyzed in this study refer to "culture-related sets of episodes" (TELLES; ZAKIR; FUNO, 2015) ${ }^{20}$, that is, sets of several interactive episodes where the following cultural topic was discussed: "Brazilian and American students' behavior". I outlined the following criteria to choose the cultural topic in question: 1) it was discussed more or less deeply along the teletandem session, since many times interactants began to address a topic but shortly after they changed it completely; 2 ) it portrayed cultural representations (cultural values and peoples' behaviors) and; 3 ) it was approached again in instances after the teletandem session.

\footnotetext{
${ }^{13}$ The data are from a research project duly approved by Research Ethics Committee of Universidade Federal de Santa Catarina (Comitê de Ética em Pesquisa com Seres Humanos - CEPSH-UFSC) with the Approval Number 1.762.956. CAAE: 56955216.8.0000.0121.

${ }^{14}$ The data used in this study are therefore from my investigation (SCHAEFER, 2019), which focused on interculturality in teletandem.

${ }^{15}$ Fictitious names in order to safeguard the participants' identity.

${ }^{16}$ For ethical issues, a consent form (Free and Informed Consent Term) was signed by all the participants in this study.

${ }^{17}$ Zoom combines online meeting, video conferencing and mobile collaboration. It also provides cloud-based video communication.

${ }^{18}$ Data from these participants were not included in this study.

${ }^{19}$ On Google Forms, it is possible to create virtual forms, e.g. open-ended, multiple choice and evaluation questions.

${ }^{20}$ For Telles, Zakir and Andreu-Funo (2015, p. 374), episódios relacionados a cultura (culture-related episodes) refer to "any part of a dialogue in which the focus is on some explanation, questioning or curiosity about aspects of one's own culture or the partner's culture" (my translation). In my study, I borrowed from the authors the term "culture-related episodes" but, due to specificities of my investigation, I adapted it to "culture-related sets of episodes".
} 
In order to facilitate and optimize the transcription process, I used Transana ${ }^{21}$. The data from the videos and audios were not fully transcribed, but only the parts deemed to be relevant for analysis (ERICKSON; SHULTZ, 1981). I translated the excerpts from Portuguese to English, upon which I take full responsibility.

The information between two parentheses, that is, (( )), as transcription conventions ${ }^{22}$, are related to the researcher's comments.

\section{DATA ANALYSIS}

In the excerpt from the teletandem session below, Heitor asked Betha what her view about Brazilian and American teachers was. This dialogue is inside a larger conversation about differences and similarities in relation to some aspects of public education schools in Brazil and in the United Sates, such as how to get into college, the quality of foreign language education and problematic student behavior.

1. Heitor: Let me just ask you another question on something I've always had doubt about.

2. Betha: Uh-huh ${ }^{23}$.

3. Heitor: When you came to Brazil $^{24} \ldots$ what is... your vision about... here you saw that the vision about teachers is a garbage... right? nobody values them you know? who values I already had teachers who left the classroom crying... how are teachers viewed both in the United States and in Brazil according to what you found when you came to Brazil?

4. Betha: So... I think this is... it's related to culture because in general you are noisier in general, right? ((smiling and making gestures with her hands to place greater emphasis on what she was explaining))

5. Heitor: Yes.

6. Betha: It's Brazil right? there’s more disruption in general... then ... it’s different you know?

$[\ldots]$

7. Betha: Ah... but like... it's not the same thing we don't throw paper at each other I've never seen this in my life...

8. Heitor: Here this is normal. ((laughter))

9. Betha: I’ve never seen the how do you say? ((imitating someone who is whistling))

10. Heitor: Whistle. (Excerpt 1 / teletandem session / my translation from Portuguese / Heitor and Betha / 19-10-2016)

In turn (1), Heitor let Betha know that he had a question, and Betha, in turn (2), showed willingness to hear Heitor's question. In line with Byram (1997), demonstrating an interest in cultural aspects of the other, as was the case by Heitor in this excerpt, is a core aspect of intercultural communication. In turn (3), even before Heitor finished stating the question, he added that the vision that one has about Brazilian teachers was "garbage", which emphatically signals his dissatisfaction with the situation of teachers in his country. Evidently, Heitor voiced his negative view while he was still framing the question, which may have influenced Betha's comments afterwards.

As can be seen, in turn (3) Heitor constructed solid representations on the topic under discussion, such as when he claimed that "nobody values them ((teachers)) you know?" (my translation from Portuguese). As Telles (2015b) reminded us earlier, essentialized

\footnotetext{
${ }^{21}$ See http://www.transana.org/ for further information on transana program.

${ }^{22}$ I used the transcription criteria proposed by Marcuschi (1997). Due to specificities of my data, I decided, on the basis of the criteria proposed by the author, to create my own transcription criteria.

${ }^{23}$ The interjection "uh-huh" is used, according to Cambridge Dictionary (see https://dictionary.cambridge.org/dictionary/english/uh-huh), "to agree with or show understanding of something that has just been said" as well as "to express agreement to what has just been said, or to mean yes"

${ }^{24}$ Betha had the opportunity to participate, a few years earlier the period of the data collection, in one exchange program in Brazil. During this time, she had been an English teacher in a public school.
} 
cultural representations are characteristic in teletandem sessions. Moreover, Belz (2005) alerts that telecollaborative exchanges can reinforce cultural stereotypes and even create others.

In turn (4), Betha uttered a homogenous view when she remarked that Brazilians are "noisier", although she used the word "in general" probably with the aim of not including all the Brazilian students in the "category of noisy students". In turn (6), in a more conclusive way, she claimed that "it's Brazil, right?", implying that "noisy" is characteristic among Brazilian students. The essentialist nature in this dialogue corroborates with Telles (2015b, p. 1), in the sense that teletandem sessions "may fall into shallow performances of sedimented and pre-given representations of self and other". Furthermore, Thorne (2006, p. 8), referring to the need to go beyond essentialisms in online intercultural communication, warns that "tandem learning may have significant limitations".

In turns 4, 6 and 7, Betha developed her line of thought by drawing upon several negative characteristics of Brazilian students as well as the duality between Brazil x the United States. By stressing the difference between "we" and "they", she voiced, specifically in turn 7, her own perspective about students' behavior ("they, the Brazilians, throw paper at each other", while "we, from the United States, do not do this"). In this regard, Telles (2015b) places emphasis on the fact that the marking of difference is a fairly common feature in the teletandem context.

It appeared that Heitor did not have the chance to distance himself from his fixed cultural representations. Even though knowledge of other cultures is deemed as an essential element (BYRAM, 1997), the discussion remained at a superficial level of exploration (BELZ, 2005; WARE, 2005; TELLES, 2015b; HELM, 2016; LOPES; FRESCHI, 2016; O’DOWD, 2016). Moreover, Heitor's opinions were left unchallenged, since Betha did not further question his generalizations, whereas Heitor missed an opportunity (WARE, 2005) to further problematize his partner's points of view. This is in harmony with Lopes and Freschi (2016), for whom, in teletandem, sessions the two interactants do not generally question each other's comments.

Later in that teletandem session, Betha also made it clear that in her country, just as in Brazil, there are educational problems, as can be seen in the following excerpt:

1. Betha: But I also... in the United States there are also school problems you know? it's like it's like you said it's not like in Brazil.

2. Heitor: No it's not.

3. Betha: Sure not at all it's not the type of perfect system but... (Excerpt 2 / teletandem session / my translation from Portuguese /Heitor and Betha / 19-10-2016)

In turn 1, Betha emphasized that problems also exist in her country, but she did not go beyond this shallow comparison. In other words, she did not provide more details about her country's public schools, nor did she mention examples of such challenges. This could explain why Heitor actually did not react to her comments. Again, just as in Excerpt 1, in Excerpt 2 there was not further exploration into the topic, but rather a mere exchange of information seemed to be taking place, which remained constant and without necessarily leading to different insights into the perspective of the other. This meets O'Dowd (2016, p. 277), who asserts that online partners are likely to pay greater attention to "what cultures may have in common at a superficial level". In the same vein, participants can be less willing to discuss certain topics than to further explore them as a means to avoid "loss of face" (WARE; KRAMSCH, 2005, p. 196). While Ware (2005, p. 66) coins this shallow approach to cultural issues in online spaces as "assumption of similarity", Ware and Kramsch (2005, p. 200), in a similar fashion, names it "the illusion of commonality".

Right after the teletandem session, the topic about public schools between Brazil and the United States came to light by Heitor in the mediation session. Initially, as a result of the knowledge he had gained through the conversation with Betha in the teletandem session, Heitor let his teacher-mediator and his classmates know, among other things, that in the United States "students do not whistle or throw paper at each other". The coming excerpt depicts how I had Heitor see the topic from other angles: 
1. Researcher: But like a suggestion for the next meeting... you may like... you can of course... still bring up this conversation... maybe right? Education this topic.

2. Heitor: YES.

3. Researcher: But like try also to go deeper... I wonder if... what she reported is actually... from the point of view of her experience and of her school only?

4. Heitor: YES, it is.

5. Researcher: Is it actually the WHOLE school system like this? of course if it's a system it should be... but in Brazil we also have right? different realities.

6. Heitor: YES.... I told her this.

7. Researcher: ((inaudible due to voice overlap)) Differently for example from São Paulo, right?

8. Heitor: Yes, yes, I told her this I said like there are schools here that don't even seem to be public...

9. Researcher: Uh-huh.

10. Heitor: Belo Horizonte for example it was shown ((probably on TV)) a school everything organized there... but like considering a hundred per cent... right guys? Let's say that... ninety-seven per cent is not like this... right? ah... everything we commented was on the basis of our vision of the school that we have in our city... of the school where we studied... of what is shown on TV and etc... (Excerpt 3 / mediation session / my translation from Portuguese / 19-10-2016)

In turns (3) and (5), Heitor was called on to distance himself from his perspectives in the discursive faultlines (KRAMSCH, 1993; MENARD-WARWICK, 2009). In other words, in line with the concept of "transgredience" (KRAMSCH, 2013, p. 62), I invited him to see himself, or his own opinions, "from the outside". Actually, I was seeking to make this participant see that one single reality could not be representative for all Brazilian schools. In turn (10), he mentioned an example of a Brazilian school where "everything is organized". In other words, having in mind that it is necessary to challenge stereotyped representations (TELLES, 2015b; LOPES; FRESCHI, 2016) and suggest other viewpoints (BYRAM, GRIBKOVA; STARKEY, 2002), this excerpt illustrates how I provided Heitor with a distinct perspective concerning the topic under discussion.

It could be argued that distancing (KRAMSCH, 1993, 2005, 2011; BYRAM, 1997; BYRAM; GRIBKOVA; STARKEY, 2002; LIDDICOAT; SCARINO, 2013), even though very timidly, was in progress in Excerpt 3. As stated by Kramsch (1993), the process of decentering is a key feature to construct the third space, while Liddicoat and Scarino (2013) underline that such a process enables participants to realize what is unfamiliar as regards cultural representations. Indeed, although in turn (10) Heitor ratified his pessimistic view of Brazilian schools, it appears that my questions made him notice that there is a school in Brazil where the quality of education provided to society stands out, although he did not give more details about it.

At a later date, Heitor mentioned in his experience report what Betha had told him in the teletandem session (Excerpt 1) about Brazilian students' behavior:

She said that she had not felt comfortable for having seen how students deal with teachers and especially how teachers are seen here in Brazil, she said that in the USA she had never seen someone throwing paper at the teacher's face. (Excerpt 4 / Heitor's experience report / my translation from Portuguese / 26-10-2016)

As can be seen, Heitor repeated what Betha had explained to him in turn (7) of Excerpt 1, that is, that unlike in Brazil, "in the United States students do not throw paper at each other". This concurs with Dervin (2014), for whom people build more cultural representations as they interact in intercultural encounters.

Some days following that experience report (Excerpt 4), I had the opportunity to discuss again the cultural topic at stake in the interview. Initially, just as the participants in Mendes's (2009, p. 97) study, who exhibited a sense "of adoration regarding everything linked to the EUA", Heitor, despite having reiterated negative characteristics of Brazilian public schools, expressed admiration for a particular aspect of the United States. That is, in response to my question on how he felt about having had the chance to learn from Betha some differences regarding the school system between Brazil and the United States, he voiced "gee incredible EVERYTHING really works there ((in the United States))" (my translation from Portuguese). In effect, by building these cultural representations, 
Heitor expressed a feeling of inferiority through which he highlighted a negative national vision attributed to teachers in Brazil. Interestingly, such a feeling meets what the writer Nelson Rodrigues, in the 1950s, named "complexo de vira-latas", a recurring phenomenon in the discourse of Brazilians, where they display a sense of inferiority as opposed to an overvaluation of aspects related to other countries.

Shortly after in that same interview, I asked Heitor whether he and Betha had drawn upon their own experience while they were speaking about that topic in the teletandem session (Excerpts 1 and 2), and I also questioned him if they had resorted to a few parameters in order to ground their arguments. He acknowledged that they had discussed that subject in the light of their own experience and that it might probably have remained at a superficial level (BELZ, 2005; WARE, 2005; TELLES, 2015b; HELM, 2016; LOPES; FRESCHI, 2016; O’DOWD, 2016). The following excerpt from the interview describes the moment in which I engaged him in further reflection:

1. Researcher: And... were you careful to tell her like "hey we're talking... about this teacher profile here".

2. Heitor: Boy I didn't make that clear to her! I generalized. ((laughing))

3. Researcher: And wouldn't it be interesting to ask her to return ((to the topic in question))...

4. Heitor: Yes, it's interesting yes.

5. Researcher: Right? because perhaps she may have understood in a different way right Heitor?

6. Heitor: Yes true! (Excerpt 5 / semi-structured interview / my translation from Portuguese / 08-11-2016)

In turn (1), I asked Heitor whether he had been careful to let Betha know that they were talking about a specific teacher profile, and, in turn (2), he acknowledged that he had indeed generalized in the teletandem session (Excerpt 1).

In this excerpt, it can be asserted that Heitor having recognized that he actually had generalized the cultural topic in question in the teletandem session (Excerpt 1) is showing that there was, albeit very timidly, an initial process of decentering, a process that Kramsch (1993, 2005, 2011, 2013), Byram (1997), Byram, Gribkova and Starkey (2002) and Liddicoat and Scarino (2013) claim to be relevant in intercultural encounters.

\subsection{DISCUSSION: SHOWING HOW THE OVERCOMING OF STEREOTYPED CULTURAL REPRESENTATIONS OCCURRED}

As has already been said, the following research question was outlined in this study: how did the overcoming of stereotyped cultural representations occur in the teletandem context investigated? It was explained in the Review of Literature that two of the four genetic domains for the study of higher mental functions are microgenetic and ontogenetic (VYGOTSKY, 1981). As regards the former, the analysis itself of each of the four excerpts presented previously can be defined as microgenetic, since my outlook was focused on the different "microevents" where the negotiation of cultural representations was taking place. Regarding the other domain, ontogenetic, there were other instances directly linked to these "microgenetic situations", which were interactively involved in the process of looking beyond fixed cultural representations. That said, drawing on the data analysis presented previously, and in response to the research question presented above, will explain further along the way in which the overcoming of stereotyped cultural representations was a process, as it occurred over time and through different instances. This means that moments subsequent to the teletandem sessions, e.g. the mediation session and the interview, were crucial for this overcoming.

In Excerpt 1 and 2, it was seen that the comparison of differences and similarities in the teletandem session with reference to the topic about Brazilian and American students' behavior remained superficial (BELZ, 2005; WARE, 2005; TELLES, 2015b; HELM, 2016; LOPES; FRESCHI, 2016; O'DOWD, 2016). Later in the mediation session (Excerpt 3), Heitor repeated some generalizations that Betha had let him know in the teletandem session, namely that "students do not throw paper at each other in the United States", and my question helped him realize that there was a school in Brazil with better quality of education, which signaled that he was looking slightly beyond his cultural generalizations. In other words, although in the teletandem session (Excerpts 1 and 2) the topic had remained stereotyped, shortly after in the mediation session (Excerpt 3) there was a decentering opportunity (KRAMSCH, 1993, 2005, 2011; BYRAM, 1997; BYRAM; GRIBKOVA; STARKEY, 2002; LIDDICOAT; SCARINO, 2013), albeit timidly, by 
Heitor. Later in the interview (Excerpt 5), in response to my contestation, another initial step towards distancing took place when he acknowledged that he had indeed generalized.

As the data analysis showed, Heitor and Betha delved themselves into an issue equated to a national reference of culture, meaning that the discussion between them revolved around the behavior of school students from Brazil vs. the United States. This attachment to a national duality was also evidenced by Menard-Warwick (2009), since in her study the culture representations "were generally of national cultures" (p. 42). Moreover, in Salomão's (2011) study the participants' view of culture was also associated with national references prior to the start of the teletandem sessions.

Linking back to Salomão’s (2011) study, culture as an interpersonal process should be viewed as part of the "pluralization of one's cultural identity" (HALL, 2006 apud SALOMÃO, 2011, p. 272). Indeed, although Heitor and Betha were aware that they were from a different country, the content of the conversations was not completely restricted to national cultures, since it was also related to idiosyncratic aspects of their cultural identities. For instance, during the teletandem session (Excerpt 1) Heitor and Betha developed explanations with particular reference to their previous experiences and their own perspectives. Hence, the process of meaning negotiation occurred in the interplay between a national framework of culture and personal contributions, in which the participants proved to be part of both national and local identities.

The interaction between Heitor and Betha in Excerpts 1 and 2 corroborates with Helm (2016), in the sense that through dialogue both the participants could put forward their own opinions and ask each other different questions. Yet, as already explained, Heitor's stable cultural representations remained uncontested in the teletandem session, which did not allow this participant to redefine them. In this connection, Thorne (2006) argues that deeper cultural understanding may not happen in tandem models. Helm (2016), on his part, remarks that in telecollaboration there seems to be a tendency to avoid issues that require further investigation or that are of a more complex nature. Lastly, O’Dowd (2016) points out that cultural differences are often played down in virtual exchanges to prevent conflicts.

Telecollaborative interactions cannot be moderated by the teacher, as was previously explained (HELM, 2016). Yet in the case of the mediation session, as a teacher-mediator, I could occupy a position "in-between" my participants, and, at the same time, I acted as the one who fostered moments of in-depth reflection upon stereotyped cultural representations. Indeed, as already observed, a possible way to promote moments of reflection is through the teacher-mediation's help (TELLES, 2015b; LEONE; TELLES, 2016; LOPES; FRESCHI, 2016). By the same token, Thorne (2006, p. 8) argues that "teacher-mediation plays a critical role in facilitating more sophisticated understandings of self and others in intercultural interaction", whereas Ware and Kramsch (2005, p. 191) stress that "teacher involvement, far from being peripheral in online learning, has been made even more important, precisely because students engage across complex linguistic and cultural lines in their computer-mediated discourse".

Lopes and Freschi (2016) and Telles (2015b), as already mentioned, contend that it is necessary to go deeper into cultural essentialisms in the mediation sessions. Hence, in order to fight against some cultural representations, I engaged Heitor in dialogue where he had the opportunity not only to talk about various aspects related to his online exchanges with Betha, but also to reflect about them. In this respect, Lopes and Freschi (2016, p. 69) posit that: "The role of the mediator in this process of development of intercultural competence is, so to speak, essential. A problematizing approach to group discussion seems to be the most effective alternative, viewing the mediator as a stimulating figure for the necessary reflection in this regard" 25 .

It may indeed be claimed that the nature of the discussions in the mediation sessions converges with the idea that through dialogue it is possible to unveil cultural assumptions and further discuss them (HELM, 2016). From this perspective, the data analysis indicated that, in the mediation session and in the interview, it was possible to expand upon the topic about differences and similarities in relation to some aspects of public education schools in Brazil and in the United Sates. As a result, Heitor could develop

\footnotetext{
${ }^{25}$ My translation. Original quote: "O papel do mediador neste processo de desenvolvimento da competência intercultural é, por assim dizer, indispensável. A proposta da problematização no grupo nos parece ser a alternativa mais eficaz, tendo no mediador a figura instigante da reflexão necessária para tal”.
} 
"an intercultural stance" (WARE; KRAMSCH, 2005, p. 203), that is, "a decentered perspective" (WARE; KRAMSCH, 2005, p. 203), even though very timidly, in relation to fixed cultural representations.

Interestingly, Heitor highlighted the following in his experience report in relation to one mediation session specifically:

What I liked the most about this interaction was that the topic had great repercussion at the moment of mediation ((in the mediation session)) in the classroom among the students, one thing I could realize several visions both views. (Excerpt 6 / Heitor's experience report / my translation from Portuguese / 03-11-2016)

Furthermore, in the last interview of the semester, I invited him to give his opinion on his participation in the teletandem sessions and in the mediation sessions. Referring to the mediation sessions but also to the process as a whole, he stressed that he had acquired knowledge and experience opportunities for his life. In the next excerpt, this participant underlined, among other things, that he had started to take account of the need to avoid fixed cultural representations:

I grew a good deal... psychosocially... spiritually everything you know? it made me see life more... how it really is did you understand? like... not to generalize [...] and this was not the vision I had you know? (Excerpt 7 / semi-structured interview / my translation from Portuguese / 07-12-2016)

This excerpt shows that Heitor had a favorable view about his experience in the teletandem activities in general. For Belz (2007, p. 156), one of the markers of the construction of interculturality "might be a gradual softening of the way in which one positions herself with respect to the 'absolute' truth of utterances" as well as the "decrease in the use of negative judgment over the course of a partnership" (p. 156). In effect, this participant's discourse in Excerpts 6 and 7 may suggest that the teletandem activities helped him to promote a growing awareness of cultural differences, which could be a sign that a possible transformation (VYGOTSKY, 1981) or, according to Liddicoat and Scarino (2013, p. 42), a possible "transformational engagement", was taking place.

\section{FINAL REMARKS}

As has already been said, in order to attain the objective of this study, that is, to discuss how the overcoming of stereotyped cultural representations occurred in the teletandem context investigated, the following research question was outlined: how did the overcoming of stereotyped cultural representations occur in the teletandem context investigated?

To sum up very briefly, in response to the research question stated above, data analysis showed that the overcoming of stereotyped cultural representations was a process, that is, it occurred over time and through different instances. In other words, instances subsequent to the teletandem session, e.g. the mediation session and the interview, were vital for this overcoming.

The application of different research techniques, mainly the experience reports and the interviews, helped me in understanding more deeply my data, which means that, through the use of different methodological resources, I was able to understand more fully my participants, promote deeper reflections and intervene pedagogically whenever needed. Hence, I suggest that future studies should also include methodological resources, such as the ones I used but also others where necessary, to better understand the complex process as regards the construction of fixed cultural representations in the teletandem context.

In my study, I collected the data over a university semester, making it difficult to determine the extent to which the learning that Heitor accomplished was applicable in other situations. For example, it is difficult to know whether this participant indeed avoided generalizations, as he had explained in the interview (Excerpt 7), with other partners in following semesters. What I really want to underline here is that longitudinal research in teletandem could help to understand how the participants deal with cultural representations over a longer period of time, for instance, two semesters. O’Dowd (2016, p. 284) places emphasis on this need when he notes that research on telecollaboration "have not attempted to evaluate the impact of virtual contact and exchange on learners 
over a period any longer than one university semester".

The teletandem activities in my study are defined as non-integrated (ARANHA; CAVALARI, 2015; LEONE; TELLES, 2016), in the sense that they were not bound to classroom contents or to a language syllabus. Considering that teletandem activities can also be institutionally integrated, as they "are embedded in regular foreign language lessons" (ARANHA; CAVALARI, 2015, p. 763), future research could draw attention to cultural representations in the classroom by having participants reflect upon their online interactions. As stated by O'Dowd (2016, p. 282), "practically none of the studies used classroom interaction transcripts or field notes to explore how teachers engaged with learners in the analysis of their online interactions".

In conclusion, drawing upon the results of this study, it can be claimed that there is a demonstrable need for the teacher-mediator to deal with intercultural issues in mediation sessions, in addition to being fully committed to the process of deconstructing some cultural representations. About this, Telles (2015b, p. 24) cautions that "if the teacher is not critically well informed about such issues, the mediation session may not transcend the level of mere reports of experience, in turn perpetuating stereotypes and sedimented conceptions of self and other". Teacher-mediators can thus encourage discussions that go beyond superficial representations.

\section{ACKNOWLEDGMENTS}

I am deeply indebted to my supervisor, Dr. Gloria Gil, for having helped me to carry out my PhD research, and to Dr. João Antonio Telles, who kindly opened the doors of the teletandem laboratory for the development of my investigation. I am also particularly grateful to TTB coordinators, teachers, and researchers for having spared no efforts to make everything work well in the period of the data-collection.

\section{REFERENCES}

ANDREU-FUNO, L. B. Teletandem: um estudo sobre identidades culturais e sessões de mediação da aprendizagem. 2015. 191 p. Tese (Doutorado em Estudos Linguísticos) - Universidade Estadual Paulista, São José do Rio Preto.

ARANHA, S.; CAVALARI, S. M. C. Institutional Integrated Teletandem: What have we been learning about writing and peer feedback? Delta, v. 31, n. 3, p. 763-780, 2015.

BELZ, J. A. Intercultural questioning, discovery and tension in internet-mediated language learning partnerships. Language and Intercultural Communication, v. 5, n. 1, p. 3-39, 2005.

BELZ, J. A. The development of intercultural communicative competence in telecollaborative partnerships. In: O'DOWD, R. (ed.). Online Intercultural Exchange: an Introduction for foreign language teachers. Clevedon: Multilingual Matters, 2007. p. 127-166.

BORGHETTI, C.; BEAVEN, A.; PUGLIESE, R. Interactions among future study abroad students: exploring potential intercultural learning sequences. Intercultural Education, v. 26, n. 1, p. 31-48, 2015.

BRAMMERTS, H. Tandem language learning via the internet and the International E-Mail Tandem Network. In: LITTLE, D; H. BRAMMERTS. (ed.). A guide to language learning in tandem via the Internet. Dublin, Centre for Language and Communication Studies, 1996. p. 9-22.

BYRAM, M. Teaching and assessing intercultural communicative competence. Clevedon: Multilingual Matters, 1997.

BYRAM, M.; GRIBKOVA, B.; STARKEY, H. Developing the intercultural dimension in language teaching: a practical introduction for teachers. Strasbourg: Council of Europe, 2002. 
DERVIN, F. Exploring 'new' interculturality online. Language and Intercultural Communication, v. 14, n. 2, p. 191-206, 2014.

DÖRNYEI, Z. Research methods in Applied Linguistics. Oxford: Oxford University Press, 2007.

ERICKSON, F.; SHULTZ, J. When is a context? Some issues and methods in the analysis of social competence. In: GREEN, J. L.; WALLAT, C. (ed.). Ethnography and language in educational settings. Norwood: Ablex, 1981. p. 147-160.

FALTIS, C. Case study methods in researching language and education. In: HORNBERGER, N. H; CORSON, D. (ed.). Encyclopedia of Language and Education. Amsterdam: Kluwer Academic Publishers, 1997. p. 145-152.

GIL, G. Third places and the interactive construction of interculturality in the English as foreign/additional language classroom. Acta Scientiarum - Language and Culture, v. 38, n. 4, p. 337-346, 2016.

HALL, S. The work of representation. In: HALL, S. (ed.). Representation: Cultural Representations and Signifying Practices. London: Sage Publications, 1997. p. 13-64.

HALL, S. A identidade cultural na pós-modernidade. Rio de Janeiro: DP\&A, 2006.

HELM, F. Facilitated dialogue in Online Intercultural Exchange. In: O’DOWD, R; LEWIS, T. (ed.). Online Intercultural Exchange: Policy, Pedagogy, Practice. New York: Outledge, 2016. p. 150-172.

KRAMSCH, C. Context and culture in language teaching. Oxford: Oxford University Press, 1993.

KRAMSCH, C. Post 9/11: Foreign languages between knowledge and power. Applied Linguistics, v. 26, n. 4, p. 545-567, 2005.

KRAMSCH, C. The symbolic dimensions of the intercultural. Language Teaching, v. 44, n. 3, p. 354-367, 2011.

KRAMSCH, C. Culture in foreign language teaching. Iranian Journal of Language Teaching Research, v. 1, n. 1, p. 57-78, 2013.

JOVCHELOVITCH, S. Knowledge in context: Representations, community and culture. London: Routledge, 2007.

KULICK, D. No. Language es Communication, v. 23, n. 2, p. 139-151, 2003.

LEONE, P.; TELLES, J. A. The teletandem network. In: O’DOWD, R.; LEWIS, T. (ed.). Online intercultural exchange: Policy, pedagogy, practice. New York: Routledge, 2016. p. 241-247.

LIDDICOAT, A.; SCARINO, A. Intercultural language teaching and learning. Oxford: Wiley-Blackwell, 2013.

LOPES, Q. B.; FRESCHI, A. C. Potenciais sequências de aprendizagem intercultural no teletandem: a importância da mediação. Revista do Gel, v. 13, n. 3, p. 49-74, 2016.

MARCUSCHI, L. A. Análise da conversação. São Paulo: Ática, 1997.

MAXWELL, J. A. Qualitative research design: an interactive approach. Thousand Oaks: Sage, 1996.

MENARD-WARWICK, J. Co-constructing representations of culture in ESL and EFL classrooms: discursive faultlines in Chile and Colombia. The Modern Language Journal, v. 9, n. 1, p. 30-45, 2009.

MENDES, C. M. Crenças sobre a língua inglesa: O antiamericanismo e sua relação como o processo de ensino-aprendizagem de professores em formação. 2009. 190 f. Dissertação (Mestrado em Estudos Linguísticos) - Universidade Estadual Paulista, São José do Rio Preto. 
O’DOWD, R. Understanding "the other side”: Intercultural learning in a Spanish-English e-mail exchange. Language Learning \& Technology, v. 7, n. 2, p. 118-144, 2003.

O'DOWD, R. Online intercultural exchange: An introduction for foreign language teachers. Clevedon: Multilingual Matters, 2007. O'DOWD, R. Telecollaboration and CALL. In: THOMAS, M.; REINDERS, H; WARSCHAUER, M. (ed.). Contemporary Computer-assisted Language Learning. London: Bloomsbury Academic, 2013. p. 123-141.

O'DOWD, R. Learning from the past and looking to the future of Online Intercultural Exchange. In: O’DOWD, R; LEWIS, T. (ed.). Online Intercultural Exchange: Policy, Pedagogy, Practice. New York: Outledge, 2016. p. 273-294.

RISAGER, K. Language and culture pedagogy: from a national to a transnational paradigm. Clevedon: Multilingual Matters, 2007.

ROCHA, C. F.; LIMA, T. C. S. Questionamentos sobre a presença do mediador na prática de interação em Teletandem. In: TELLES, J. A. (Org.). Teletandem: Um Contexto Virtual, Autônomo e Colaborativo para a Aprendizagem de Línguas Estrangeiras no Século XX. Campinas, Pontes, 2009. p. 231-241

SALOMÃO, A. C. B. On-line collaborative learning for in-service teacher education. Journal of Emerging Technologies in Web Intelligence, v. 3, n. 4, p. 268-272, 2011.

SCHAEFER, R. The co-construction of interculturality in the project Teletandem Brasil: foreign languages for all. $2019.597 \mathrm{f}$. Tese (Doutorado em Inglês: Estudos Linguísticos e Literários) - Universidade Federal de Santa Catarina, Florianópolis.

TELLES, J. A. Teletandem: Tranculturalidade nas interações on-line em línguas estrangeiras por webcam. Research Project: Universidade Estadual Paulista, Brazil, 2011.p. 1-24.

TELLES, J. A. Learning foreign languages in teletandem: Resources and strategies. DELTA - Revista de Estudos em Linguística Teórica e Aplicada, v. 31, n. 3, p. 603-632, 2015a.

TELLES, J. A. Teletandem and performativity. Revista Brasileira de Linguística Aplicada, v. 15, n. 1, p. 1-30, 2015 b.

TELLES, J. A.; VASSALLO, M. L. Foreign language learning in-tandem: Teletandem as an alternative proposal in CALLT. The ESPecialist, v. 27, n. 2, p. 189-212, 2006.

TELLES, J. A.; ZAKIR, M. A.; ANDREU-FUNO, L. B. A. Teletandem e episódios relacionados a cultura. Delta, v. 31, n. 2, p. 359$389,2015$.

THORNE, S. L. Pedagogical and praxiological lessons from Internet-Mediated Intercultural Foreign Language Education Research. In: BELZ, J. A.; THORNE, S. L. (ed.). Internet-Mediated Intercultural Foreign Language Education. Boston: Heinle \&Heinle, 2006. p. $2-30$.

VAN LIER, L. The ecology and semiotics of language learning: A sociocultural perspective. Dordrecht: Kluwer Academic Publishers, 2004.

VASSALLO, M. L. Teletandem ou tandem tele-presencial? In: TELLES, J. A. (org.). Teletandem: Um contexto virtual, autônomo e colaborativo para a aprendizagem de línguas estrangeiras no século XXI. Campinas, Pontes, 2009. p. 185-197.

VASSALLO, M. L; TELLES, J. A. Foreign language learning in-tandem:Theoretical principles and research perspectives. The ESPecialist, v. 27, n. 1, p. 83-118, 2006. 
VELOSO, F. S.; ALMEIDA, V. B. A fala facilitadora de dois interagentes no contexto de aprendizagem de LE no Teletandem. In: TELLES, J. A. (org.). Teletandem: Um contexto virtual, autônomo e colaborativo para a aprendizagem de línguas estrangeiras no século XXI. Campinas: Pontes, 2009. p. 149-168.

VYGOTSKY, L. S. Mind in society: The development of higher psychological processes. Cambridge: Harvard University Press, 1978.

VYGOTSKY, L. S. The genesis of higher mental functions. In: WERTSCH, J. V. (ed.). The concept of activity in Soviet psychology. Armonk: Sharpe, 1981.p. 144-188.

WARE, P. D. "Missed" communication in online communication: Tensions in a German-American telecollaboration. Language Learning \& Technology, v. 9, n. 2, p. 64-89, 2005.

WARE, P. D.; KRAMSCH, C. Toward an intercultural stance: Teaching German and English through telecollaboration. The Modern Language Journal, v. 89, n. 2, p. 190-205, 2005.

WOOD, D.; BRUNER, J.; ROSS, G. The role of tutoring in problem solving. Journal of Child Psychology and Child Psychiatry, v. 17, p. 89-100, 1976.

\section{(ㄷ) (1) $(\circledast$}


